\title{
PENGARUH DIVIDEND PAYOUT RATIO, RETURN ON ASSET, DAN PENJUALAN TERHADAP HARGA SAHAM PERUSAHAAN MANUFAKTUR DI BURSA EFEK INDONESIA
}

\author{
Binsar Sihombing, SE, M.Si
}

\begin{abstract}
ABSTRAK
Binsar Sihombing, SE, M.Si, This study aimed to analyze the effect of dividend payout ratio, return on assets and sales of company stock at Indonesia Stock Exchange. To achieve these objectives, sampling in this study using purposive sampling method. Population used in this study are listed manufacturing companies in Indonesia PT.Bursa Securities in 2009 as many as 153 companies, of the population taken as a sample of 42 companies. Analyses were performed with multiple linear regression models. Note that the discussion of the results, the dividend payout ratio, return on assets and sales have a positive effect on stock prices. Dividend payout ratio has a regression coefficient of 0.180311 with a probability of 0.0847 or 8.47 percent. Return on assets has a regression coefficient of 0.54029 with a probability of 0.0093 or 0.93 percent. Sedangka sales have koefien regression of 0.428178 with a probability of 0.0000 , or 0 percent.
\end{abstract}

\section{PENDAHULUAN}

Penelitian yang berkaitan dengan kemampuan informasi keuangan dengan menggunakan rasio-rasio keuangan sebagai variabel independen untuk memprediksi tingkat return saham telah digunakan Abarbanell and Bushee (1998), Matchfoedz (1994), Parawiyati dkk. (1998). Aryati dan Sandiyani (2001), Wijayati dkk. (2005). Menurut Manurung dan Siahaan (2004), penggunaan rasio keuangan dalam memprediksi harga-harga saham perusahaam manufaktur menghasilkan tingkat return yang underestimate. Hubungan antara rasio keuangan dengan tingkat return investasi saham perusahaan manufaktur adalah positip.

Laporan keuangan sebagai hasil akhir dari proses akuntansi dirancang untuk menyediakan data dan informasi bagi manajemen perusahaan, investor, calon investor, kreditur dan pihak lain yang berkepentingan untuk pengambilan keputusan investasi, kredit, dan keputusan lainnya. Informasi yang diperlukan oleh para investor di pasar modal tidak hanya informasi yang bersifat fundamental saja, akan tetapi juga informasi yang bersifat teknikal. Informasi yang bersifat fundamental dan yang bersifat teknikal diperoleh dari kondisi intern perusahaan, faktor ekonomi dan keuangan, faktor politik, kebijakan moneter dan kebijakan fiskal. Informasi yang diperoleh dari kondisi intern perusahaan yang lazim digunakan adalah informasi laporan keuangan. Informasi fundamental dan teknikal tersebut dapat digunakan sebagai dasar bagi investor untuk memprediksi tingkat return dan risiko dari investasi saham serta aktivitas investor di pasar modal.

Informasi yang diperoleh dari laporan keuangan mempunyai kemampuan prediksi sehingga investor terbantu dalam mengambil keputusan investasi (Beaver et.al, 1998). Penyediaan informasi keuangan secara transparan dan bertanggungjawab dengan sendirinya akan mendorong investor untuk berinvestasi pada pasar modal. Penyediaan informasi juga menciptakan kemudahan pembiayaan perusahaan sehingga kinerja perusahaan mengalami perkembangan positip.

Manajer perusahaan dapat melakukan investasi dengan risiko tinggi, jika investasi tersebut berhasil maka harga saham perusahaan naik dan tingkat return pemegang saham naik, sebaliknya pemegang obligasi perusahaan memperoleh tingkat return yang tetap dalam bentuk pembayaran kupon obligasi. Sebaliknya jika investasi tersebut gagal maka harga saham perusahaan turun dan tingkat return pemegang saham negatip, sebaliknya nilai 
jaminan bagi pemegang obligasi perusahaan turun atau pembayaran obligasi kemungkinan akan gagal dan berisiko (Weston dan Copeland, 1992). Masalah ini disebut agency problem yang menggambarkan bahwa derajat risk aversion dari manajer perusahaan relatif rendah. Hal ini menjelaskan bahwa informasi tentang sikap manajer perusahaan terhadap risiko juga sangat diperlukan oleh investor dan kreditur.

Peningkatan profitabilitas perusahaan sebagai salah satu ukuran kinerja keuangan mengindikasikan peningkatan nilai ekuitas atau saham perusahaan. Indikator profitabilitas berarti telah memasukkan seluruh informasi kejadian yang tercakup dalam profitabilitas dengan penekanan pada periode sekarang, sehingga informasi profitabilitas dan informasi lainnya dapat digunakan untuk memprediksi apakah investasi pada saham perusahaan menghasilkan tingkat return yang menguntungkan pada masa datang.

Penelitian ini menggunakan informasi laporan keuangan seperti dividend payout ratio, return on asset dan penjualan dalam menganalisis pengaruhnya terhadap harga saham pada perusahaan manufaktur di Bursa Efek Indonesia. Penelitian ini berbeda dengan penelitian terdahulu karena selain variabel yang digunakan berbeda, juga model prediksi dan kondisi ekonomi yang relatif berbeda. Pengaruh rasio keuangan terhadap tingkat return positip merupakan informasi yang sangat penting bagi pengambil keputusan, investor dan kreditur. Tingkat return positip dari investasi saham perusahaan manufaktur di Bursa Efek Indonesia akan menjelaskan perusahaan yang profitable.

Penelitian ini difokuskan untuk menganalisis pengaruh dividen payout ratio, return on asset dan penjualan terhadap harga saham perusahaan manufaktur yang terdaftar di Bursa Efek Indonesia. Hasil penelitian ini diharapkan dapat menjadi informasi penting bagi pihak yang berkepentingan dalam melakukan investasi khususnya investasi pada saham biasa, sehingga dapat memaksimalkan hasil yang diharapkan.

\section{Kerangka Konseptual}

Laporan keuangan yang diterbitkan perusahaan merupakan salah satu informasi yang dapat digunakan untuk menilai kinerja perusahaan. Kinerja perusahaan dapat diukur dengan berbagai rasio keuangan. Berdasarkan analisis rasio keuangan, investor dan investor potensial dapat menentukan keputusan investasi yang lebih profitable. Keputusan investasi yang profitable diperoleh dengan melakukan prediksi terhadap probabilitas profitable return investasi saham di masa yang akan datang berdasarkan rasio keuangan.

Financial Accounting Standards Board (FASB) menguraikan bahwa tujuan laporan keuangan adalah untuk memberikan informasi yang berguna untuk keputusan bisnis. Laporan keuangan menjadi alat utama bagi perusahaan untuk menyampaikan informasi keuangan mengenai pertanggungjawaban pihak manajemen (Schipper and Vincent, 2003).

Harianto dan Sudono (1998), menyatakan bahwa pengguna dan pemanfaat laporan keuangan adalah pemegang saham, investor, manajer, karyawan, pemasok dan kreditor, pelanggan, pemerintah dan pengguna lainnya. Pemegang saham akan menilai kinerja manajemen sebagai pihak yang diberi tanggungjawab untuk mengelola sumber daya pemegang saham. Investor memerlukan informasi keuangan untuk mengambil keputusan investasi apakah harus membeli, menahan atau menjual investasinya. Demikian juga pihak lain yang berkepentingan terhadap laporan keuangan perusahaan dapat menggunakan informasi keuangan untuk pengambilan keputusan sesuai keperluannya.

Salah satu bentuk informasi laporan keuangan yang penting dalam penilaian kinerja perusahaan 
adalah rasio-rasio keuangan. Dengan rasio-rasio keuangan dapat diperoleh informasi tentang berbagai indikator keuangan yang dapat mengungkapkan kondisi keuangan suatu perusahaan maupun kinerja yang telah dicapai untuk suatu periode tertentu.

Brigham, (1998) menguraikan bahwa pihak suplier lebih menekankan jaminan yang ditunjukkan besarnya aktiva lancar perusahaan. Pemegang saham preferen dan obligasi lebih menitik beratkan pada aliran kas jangka panjang, sementara pemilik dan calon investor menekankan pada tingkat profitabilitas dan resiko karena kestabilan harga saham sangat tergantung dengan tingkat keuntungan yang diperoleh dan dividen di masa datang. Bagi manajemen akan lebih memperhatikan semua aspek analisis keuangan apakah yang sifatnya jangka pendek maupun jangka panjang sebagai tanggungjawab atas pengelolaan operasi perusahan.

Dengan perbedaan kepentingan dari berbagai pihak yang berkepentingan terhadap laporan keuangan dan tidak ada satu analisis rasio yang dapat menjawab semua kepentingan tersebut, maka dikembangkan empat kelompok rasio keuangan (Brigham, 1998). Keempat kelompok rasio tersebut adalah rasio likuiditas, rasio aktivitas, rasio leverage dan rasio profitabilitas.

Ou dan Penman (1989) memprediksi return saham dengan menggunakan stepwise regression. Hasil penelitiannya menunjukkan bahwa rasio keuangan seperti rasio likuiditas, rasio leverage, rasio aktivitas dan rasio profitabilitas mempunyai pengaruh yang signifikan untuk memprediksi return saham.

Machfoed (1994), menguji manfaat rasio keuangan dalam memprediksi perubahan laba perusahaan di masa depan. Hasil penelitiannya menunjukkan bahwa rasio keuangan signifikan sebagai variabel dalam memprediksi perubahan laba di masa datang. Sandiyani dan Aryati (2001) melakukan penelitian untuk mengetahui hubungan antara variabel informasi keuangan dengan kemampuan prediksi perubahan laba dan arus kas untuk satu tahun ke depan. Hasil penelitian menunjukkan bahwa informasi keuangan mempunyai hubungan yang kuat. Wijayanti dkk. (2005), menemukan bahwa informasi keuangan dapat digunakan untuk memprediksi perubahan laba, baik sebelum maupun sesudah krisis moneter.

Ball dan Brown (1968), menyatakan bahwa informasi yang terkandung dalam laporan keuangan berkorelasi dengan return saham residual. Hasil penelitiannya didukung oleh penelitian. Beaver (1968) yang menyimpulkan bahwa informasi yang dihasilkan laporan keuangan berupa rasio-rasio keuangan mempunyai pengaruh yang positip terhadap variabilitas perubahan harga saham.

Battacharya (1979), Jhon and Williams (1985), Miller and Rock (1985) menemukan bahwa pengumuman dividen melalui laporan keuangan perusahaan membawa sinyal yang berarti dalam pengambilan keputusan oleh investor yang tercermin dalam harga saham. Hasil penelitian Landsman (1986), Amir (1993), Francis dan Schipper (1999), menunjukkan bahwa aktiva dan kewajiban berhubungan dengan harga saham. Hasil penelitian Ohlson ( 1995), membuktikan bahwa nilai buku dan profitabilitas perusahaan memiliki hubungan yang kuat terhadap harga saham. Hasil studi Sloan (1996), menunjukkan bahwa harga saham bereaksi jika investor percaya pada earning. Kormedi dan Lipe (1987) menguji hubungan antara perubahan laba dan persistensi laba dengan return saham. Hasil penelitiannya menunjukkan bahwa koefisien respon laba berkorelasi positip terhadap return saham. Dechow (1994), meneliti laba akuntansi dan arus kas sebagai ukuran dalam nenilai kinerja perusahaan. Hasil penelitiannya menunjukkan bahwa laba akuntansi merupakan ukuran penilaian kinerja perusahaan.

Taggart (1977), menemukan bahwa peningkatan rasio hutang berpengaruh positip terhadap 
return saham, mengindikasikan bahwa struktur modal perusahaan belum optimal sehingga peningkatan manfaat dari penggunaan hutang lebih besar dari biaya penggunaan hutang. Tetapi apabila struktur modal perusahaan sudah optimal, maka peningkatan hutang akan berpengaruh negatip terhadap return karena manfaat penggunaan hutang lebih kecil dari biaya penggunaan hutang.

Kajian teoritis di atas menunjukkan bahwa rasio keuangan, yaitu rasio likuiditas, rasio leverage, rasio aktivitas dan rasio profitabilitas mempunyai hubungan kausal dengan tingkat return saham. Oleh sebab itu, rasio keuangan dapat digunakan untuk memprediksi probabilitas profitable atau nonprofitable investasi saham perusahaan manufaktur di Bursa Efek Jakarta.

\section{Hubungan Kausal Dividend Payout Ratio, Return on Asset dan Penjualan terhadap Harga Saham}

Nilai perusahaan adalah sama dengan nilai saham (jumlah lembar saham yang dikalikan dengan nilai pasar perlembar saham) ditambah dengan nilai pasar hutang, dengan demikian naiknya nilai saham dengan sendirinya akan meningkatkan nilai perusahaan dengan asumsi bahwa besarnya nilai hutang adalah konstan, maka nilai perusahaan tercermin pada harga saham. Dengan kata lain, nilai saham mencerminkan nilai perusahaan dan nilai kekayaan bersih perusahaan. Harga saham dari waktu ke waktu mengalami perubahan, naik, tetap dan turun. Pergerakan harga saham berfluktuasi umumnya diakibatkan oleh permintaan dan penawaran terhadap suatu saham. Naik turunnya permintaan dan penawaran terhadap suatu saham diakibatkan beberapa faktor yang merupakan pertimbangan bagi setiap investor atau calon investor dalam memutuskan apakah ia akan membeli atau menjual saham. Untuk melihat sejauh mana pengaruh Net penjualan, dividen payout ratio dan return on asset terhadap harga saham biasa dapat kita lihat dari model perhitung harga saham konstan pada persamaan berikut:

$$
\mathbf{P}=\frac{D_{1}}{k-g}
$$

dimana, $\mathrm{P}$ adalah harga saham, $\mathrm{D}_{1}$ menunjukkan dividen pada periode akhir tahun, $\mathrm{k}$ adalah tingkat kapitalisasi ekuitas dan g tingkat pertumbuhan dividen.

Menurut Husnan (2001) dividen merupakan sebagian dari laba yang dibagikan sehingga dapat dikatakan bahwa dividen adalah persentase pembayaran dividen (dividen payout ratio) dikali dengan laba (earning per share). Hal ini dapat dinyatakan melalui rumus sebagai berikut:

$$
\text { Dn }=(1-S) \text { En }
$$

Dimana, $\mathrm{S}$ adalah laba ditahan, 1-S merupakan rasio pembayaran dividen dan En merupakan laba per lembar saham. Dengan demikian, persamaan (2) dapat dirubah menjadi:

\section{Dn $=$ DPR $\times$ EPS}

Untuk mengetahui hubungan kausal variabel dividen payout ratio terhadap harga saham, maka persamaa (3) disubstitusi pada persamaa (1), sehingga diperoleh persamaan (4) berikut:

$$
\mathbf{P}=\frac{D P R_{n} x E P S_{n}}{k-g}
$$

Dari persamaan (4) dipeoleh gambaran bahwa variabel dividend payout ratio $\left[\mathrm{DPR}_{\mathrm{n}}\right]$ memiliki pengaruh yang positip terhadap harga saham. Artinya, bila dividend payout ratio semakin meningkat, maka haraga saham akan naik dengan asumsi yang lain konstan. 
Menurut Husnan (2001), EPS dapat dihitung dari perkalian antara return on equity (ROE) dengan Book Value (BV). Sementara return on equity merupakan perkalian antara return on asset dengan leverage yang dapat dituliskan sebagai berikut

ROE $=$ ROA $\times$ Leverage

Dengan demikian, persamaan (4) dapat dirubah menjadi:

$$
\begin{aligned}
& \mathbf{P}=\frac{D P R_{n} x R O E x B V}{k-g} \\
& \mathbf{P}=\frac{D P R_{n} x(\text { ROAxLeverage }) x B V}{k-g}
\end{aligned}
$$

Persamaa (7) menjelaskan bahwa hubungan kausal antara dividen payout ratio dan return on asset terhadap harga saham berhubungan positif.

Untuk mengetahui hubungan kausal variabel penjualan terhadap harga saham dilakukan dengan persamaan berikut:

$$
\begin{gathered}
\text { ROA }=\frac{\text { Lababersih }}{\text { Penjualan }} \times \frac{\text { Penjualan }}{\text { Total Asset }} \\
\mathbf{P}=\frac{D P R_{n} \times\left[\left(\frac{E A T}{\text { Penjualan }} \times \frac{\text { Penjualan }}{T A}\right)(\text { Leverage })\right] \times B V}{k-g}
\end{gathered}
$$

Persamaan (9) menjelaskan bahwa dividen payout ratio, return on asset dan penjualan memiliki hubungan yang positip terhadap harga saham.

\section{METODE PENELITIAN}

Populasi dalam penelitian ini adalah perusahaan manufaktur yang terdaftar di Bursa Efek Indonesia selama tahun 2009 yaitu sebanyak 153 perusahaan. Sampel yang digunakan sebanyak 42 perusahaan. Pengambilan sampel dilakukan secara puposive sampling, yaitu penarikan sampel berdasarkan kriteria tertentu. Skala pengukuran dalam adalah skala rasio. Data yang dikumpulkan adalah data sekunder. yang diambil dengan teknik dokumentasi dari Indonesian Capital Market Directory 2010.

Model Analisis yang digunakan adalah model regresi linier berganda yang dirumuskan sebagai berikut :

$$
\begin{aligned}
\mathrm{CP}=\beta_{0} & +\beta_{1} \mathrm{DPR}+\beta_{2} \mathrm{ROA}+\beta_{3} \mathrm{SAL}+\varepsilon \\
\operatorname{dimana}: \mathrm{CP} & =\text { Closing Price [rupiah] } \\
\mathrm{DPR} & =\text { Dividen Payout Ratio [persentasi] } \\
\mathrm{ROA} & =\text { Return on Asset [persentasi] } \\
\mathrm{SAL} & =\text { Penjualan Netto [ribuan rupiah] } \\
\mathrm{i} & =\text { Nama perusahaan } 1,2,3, \ldots \ldots . .42
\end{aligned}
$$

\section{Hasil Analisis dan Pembahasan}

Variabel yang digunakan dalam penelitian ini terdiri dari harga saham [CP] sebagai variabel terikat dan variabel bebas terdiri dari dividen payout ratio [DPR], return on asset [ROA], dan penjualan [SAL].

Tabel 1 Hasil Penaksiran Model 
Method: Least Squares

Included observations: 42

\begin{tabular}{|c|c|c|c|c|}
\hline Variable & Coefficient & Std. Error & t-Statistic & Prob. \\
\hline DPR & 0.180311 & 0.101906 & 1.769379 & 0.0847 \\
\hline ROA & 0.540209 & 0.197309 & 2.737890 & 0.0093 \\
\hline SAL & 0.428178 & 0.031950 & 13.40130 & 0.0000 \\
\hline R-squared & 0.296497 & Mean dependent var & & 7.149048 \\
\hline Adjusted R-squared & 0.260420 & S.D. dependent var & & 1.497766 \\
\hline S.E. of regression & 1.288061 & Akaike info criterion & & 3.412902 \\
\hline Sum squared resid & 64.70495 & Schwarz criterion & & 3.537022 \\
\hline Log likelihood & -68.67095 & Durbin-Watson stat & & 1.998944 \\
\hline
\end{tabular}

Sumber: Hasil pengolahan data dengan Eviews 4.1

Tabel 1 menunjukan pengaruh variabel dividen payout ratio [DPR], return on asset [ROA], dan penjualan $[\mathrm{SAL}]$ terhadap variabel harga saham [CP] adalah positif. Pengujian secara parsial menunjukkan bahwa variabel return on asset [ROA] dan penjualan [SAL] memiliki pengaruh yang positif dan signifikan terhadap harga saham pada perusahaan manufaktur di Bursa Efek Indonesia sedangkan dividen payout ratio [DPR] mempunyai pengaruh positif yang tidak signifikan terhadap harga saham pada perusahaan manufaktur di Bursa Efek Indonesia.

Uji normalitas dilakukan dengan mengamati penyebaran stochastic term error yang dihasilkan oleh model regresi, yaitu nilai Jargue-Bera sebesar 1.309674 dengan probabilitas 0.519527 atau 51.9527 persen. Berdasarkan hasil pengujian tersebut menunjukan bahwa nilai Jargue-Bera tidak signifikan pada tingkat $\alpha=5$ persen. Dengan demikian model yang digunakan pada penelitian ini telah mengikuti asumsi normalitas pada tingkat $\alpha=5$ persen, maka variabel bebas yang dimasukkan dalam penelitian ini dapat digunakan sebagai instrumen penentu dalam keputusan berinvestasi.

Tabel 2 Uji Homokedastisitas

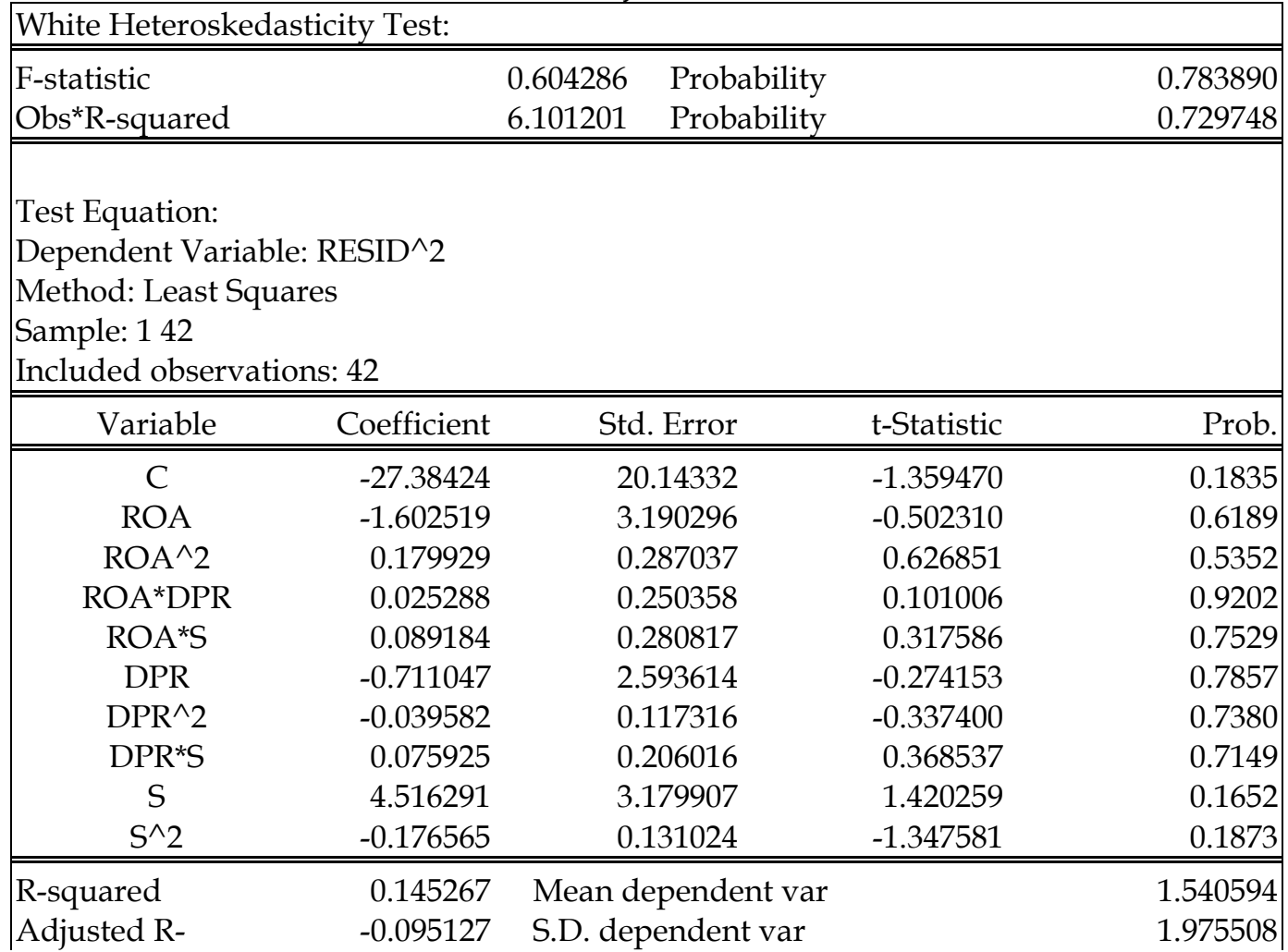


squared

$\begin{array}{llll}\text { S.E. of regression } & 2.067336 & \text { Akaike info criterion } & 4.494656\end{array}$

$\begin{array}{llll}\text { Sum squared resid } & 136.7641 & \text { Schwarz criterion } & 4.908387\end{array}$

$\begin{array}{llll}\text { Log likelihood } & -84.38777 & \text { F-statistic } & 0.604286\end{array}$

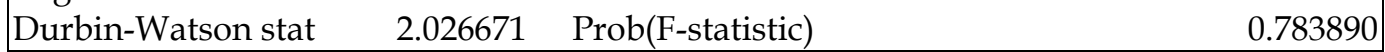

Sumber: Hasil pengolahan Data dengan eviews 4.1

Heteroskedastisitas merupakan taksiran koefesien yang tidak efisien karena varians tiap pengamatan berbeda. Untuk mendeteksi masalah tersebut dilakukan uji White's General Heteroscedasticity test sebagaimana ditunjukkan pada tabel 2.

Hasil uji white's general heteroscedacity menunjukkan bahwa nilai statistik $X^{2}=\mathrm{N} \times \mathrm{R}^{2}$ adalah 6.101201 dengan probabilitas 0.729748 atau 72.9748 persen. Hasil pengujian tersebut menunjukan bahwa gejala heterokedastisitas tidak muncul dengan tingkat signifikan sebesar lima persen. Oleh karena itu besar koefisien variabel bebas yaitu dividen payout ratio [DPR], return on asset [ROA], dan penjualan [SAL] pada model regresi layak digunakan untuk memprediksi harga saham pada perusahaan manufaktur di Bursa Efek Indonesia.

Tabel 3 Uji Autokorelasi

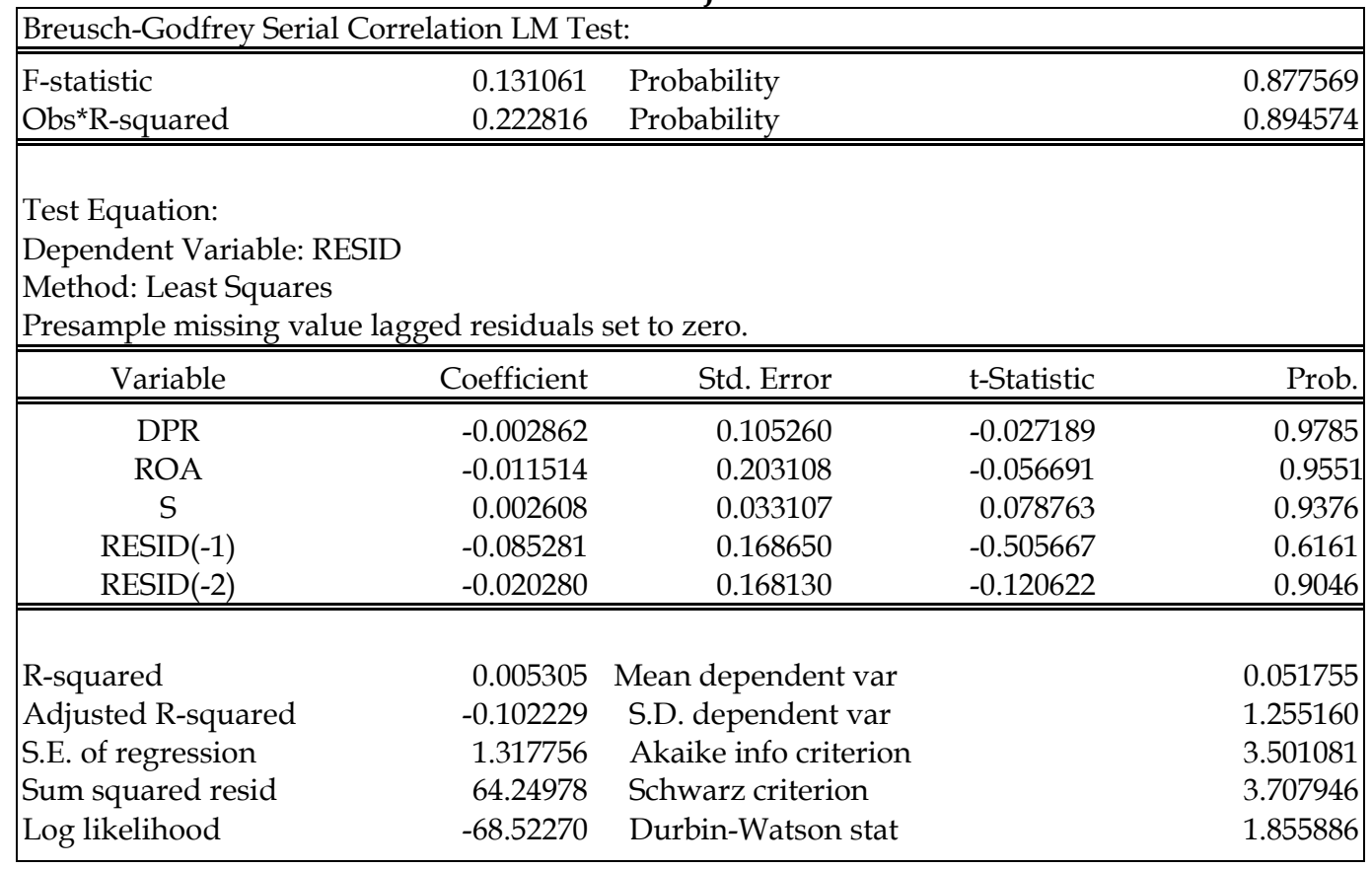

Sumber: Hasil pengolahan data dengan Eviews 4.1

Uji autokorelasi dimaksudkan untuk mendeteksi terjadinya korelasi stochastik dan error $(\varepsilon)$ antara periode $t$ dan periode sebelumnya untuk data time series sedangkan pada data cross section yaitu adanya korelasi stochastik dan error antara perusahaan yang satu dengan perusahaan yang lain. Pada tabel 3 ditunjukan bahwa nilai statistik $\mathrm{X}^{2}=\mathrm{NxR}^{2}$ adalah 0.222816 dengan probabilitas 0.894574 atau 89.4574 persen.

Hasil pengujian tersebut menunjukan bahwa varian stochastic term error tidak signifikan pada tingkat $\alpha=5$ persen, maka koefisien model regresi harga saham tidak mengalami autokorelasi.

Uji multikolinieritas digunakan untuk mengetahui ada tidaknya korelasi linier diantara variabel-variabel bebas dalam model regresi. Untuk menguji ada tidaknya multikolinieritas digunakan varians inflating vactor (VIF). 
Tabel 4 Matrix korelasi antar variabel bebas dan inflating factor untuk uji Multikolinieritas

\begin{tabular}{|cccc|}
\hline Variabel & ROA & DPR & SAL \\
ROA & 0.038931 & -0.003281 & -0.004587 \\
DPR & -0.003281 & 0.010385 & -0.001251 \\
SAL & -0.004587 & -0.001251 & 0.001021 \\
ROA & 1.04058 & 0.99673 & 0.99543 \\
DPR & 0.99672 & 1.0105 & 0.99875 \\
SAL & 0.99543 & 0.99875 & 1.00103 \\
\hline
\end{tabular}

Sumber: Hasil pengolahan data dengan eviews 4.1

Berdasarkan perhitungan pada tabel 4, nilai varians inflating vactor [VIF] lebih kecil dari 10, sehingga tidak terjadi multikolinieritas yang serius. Dengan demikian, variabel dividen payout ratio [DPR], return on asset [ROA], dan penjualan [SAL] tidak mengalami multikolinieritas yang sempurna. Model yang digunakan sudah sesuai untuk menentukan seberapa besar pengaruh dividen payout ratio [DPR], return on asset [ROA], dan penjualan [SAL] terhadap harga saham perusahaan manufaktur di Bursa Efek Indonesia. Hasil analisis regresi menunjukkan sebagai berikut :

$$
\mathrm{CP}_{i t}=\mathrm{ROA}^{0.540209} \mathrm{DPR}^{0.180311} \mathrm{SAL}^{0.428178}
$$

Pada tabel 1 menunjukan bahwa variabel return on asset [ROA] mempunyai koefisien regresi positif sebesar 0.540209. Hasil penelitian ini menunjukan bahwa return on asset [ROA] mempunyai pengaruh yang positif terhadap harga saham, artinya peningkatan satu persen return on asset [ROA] akan menaikan harga saham perusahaan manufaktur di Bursa Efek Indonesia sebesar 0.540209 persen. Hasil penelitian ini konsisten dengan teori yang menyatakan bahwa return on asset [ROA] mempunyai pengaruh positif terhadap harga saham. Pengaruh positif yang ditunjukan menjelaskan bahwa semakin tinggi return on asset [ROA] akan menaikkan harga saham, sebaliknya jika return on asset [ROA] semakin kecil maka harga saham akan turun.

Meningkatnya return on asset [ROA] menunjukkan bahwa laba bersih yang tersedia bagi pemegang saham akan semakin besar dan dividen yang dibagikan kepada pemegang saham juga semakin besar.

Dividen payout ratio [DPR] mempunyai pengaruh yang positif dan signifikan terhadap harga saham pada perusahaan manufaktur yang telah terdaftar di Bursa Efek Indonesia. Peningkatan dividen payout ratio [DPR] cenderung akan meningkatkan harga saham. Menurut the zero growth model, the constant growt model dan the multiple growth model, bahwa peningkatan dividen yang diterima akan meningkatkan nilai saham.

Dari model regresi diketahui bahwa pengaruh dividen payout ratio [DPR] terhadap harga saham sebesar 0.180311 atau 18.0311 persen, artinya jika dividen payout ratio [DPR] perusahaan naik satu persen maka harga saham akan naik sebesar 0.180311 atau 18.0311 persen. Hasil penelitian ini konsisten dengan teori yang menyatakan bahwa dividen payout ratio [DPR] mempunyai pengaruh yang positif terhadap harga saham. 
Kebijakan dividen merupakan hal penting bagi manager keuangan karena melibatkan dua pihak yang berkepentingan yaitu pemegang saham dan perusahaan. Perubahan kebijakan pembayaran dividen akan menghasilkan dampak yang berlawanan sesuai dengan kepentingan masing-masing yang terlibat. Bila dividen dibayarkan seluruhnya, maka kepentinga perusahaan berupa cadangan akan terabaikan. Sebaliknya bila laba akan ditahan seluruhnya, maka kepentingan pemegang saham akan uang kas terabaikan.

Secara parsial dividen payout ratio [DPR] mempunyai pengaruh yang tidak signifikan terhadap harga saham. Dalam penelitian ini pengaruh positif dividen payout ratio [DPR] terhadap harga saham tidak signifikan pada tingkat $\alpha=5$ persen, ini disebabkan karena investor tidak akan menahan atau menjual sahamnya sampai akhir tahun atau pada saat pembagian dividen tetapi investor lebih cenderung menahan atau menjual sahamnya dengan mengikuti pergerakan harga saham yang terjadi di pasar. Harga pasar saham selalu berfluktuasi yaitu naik turun setiap saat dan bukan setiap akhir tahun. Dengan demikian dividen payout ratio [DPR] tidak signifikan mempengaruhi harga saham dan ini menunjukan bahwa investor akan lebih senang menerima pendapatan dari capital gain dibandingkan dari pendapatan dividen.

Penjualan [SAL] mempunyai pengaruh yang positif dan signifikan terhadap harga saham pada perusahaan manufaktur yang terdaftar di Bursa Efek Indonesia. Peningkatan volume penjualan perusahaan manufaktur yang terdaftar di Bursa Efek Indonesia dapat meningkatkan harga saham dan sebaliknya, penurunan volume penjualan perusahaan manufaktur yang terdaftar di Bursa Efek Indonesia akan dapat menurunkan harga saham.

Pada Tabel 1 menunjukan bahwa penjualan [SAL] mempunyai pengaruh yang positif dan signifikan terhadap harga saham dengan tingkat probabilitas 0.0000. Dari model regresi ditunjukan bahwa pengaruh penjualan [SAL] terhadap harga saham sebesar 0.428178. Hal ini menunjukan bahwa jika penjualan naik sebesar satu persen maka harga saham biasa akan naik sebesar 0.428178 persen.

Hasil penelitian ini konsisten dengan teori yang menyatakan bahwa penjualan mempunyai pengaruh yang positif terhadap harga saham. Pada tingkat penjualan yang rendah akan memberikan laba perlembar saham yang rendah dan penjualan yang terus-menerus meningkat akan memberikan peningkatan laba per saham akan makin tinggi. Besarnya pengaruh penjualan terhadap harga saham, merupakan salah satu indikator penting yang perlu diperhatikan seorang investor dalam berinvestasi pada saham biasa pada perusahaan manufaktur yang terdaftar di Bursa Efek Indonesia.

\section{KESIMPULAN}

Model yang digunakan untuk menganalisis pengaruh dividend payout ratio, return on asset dan penjualan adalah regresi linier berganda. Hasil analisis menunjukkan bahwa variabel dividend payout ratio, return on asset dan penjualan mempunyai pengaruh yang positip terhadap harga saham perusahaan manufaktur di Bursa Efek Indonesia. Artinya, peningkatan dividend payout ratio, return on asset dan penjualan akan meningkatkan terhadap harga saham perusahaan manufaktur di Bursa Efek Indonesia.

Return on asset (ROA) mempunyai pengaruh yang positif terhadap harga saham perusahaan industri manufaktur di Bursa Efek Indonesia dengan koefisien regresi sebesar 0.540209 pada tingkat probabilitas 0.0093 atau 0.93 persen. 
Dividen payout ratio mempunyai pengaruh yang positif terhadap harga saham pada perusahaan industri manufaktur di Bursa Efek Indonesia dengan nilai koefisien regresi sebesar 0.1801311 dan tingkat probabilitas 0.0847 atau 8.47 persen.

Penjualan mempunyai pengaruh yang positif terhadap harga saham pada perusahaan industri manufaktur di. Bursa Efek Indonesia dengan koefisien regresi sebesar 0.428178 dan tingkat probabilitas 0.0000 atau nol persen.

\section{DAFTAR PUSTAKA}

Abarbanel, J. and J. B. Bushee. 1998. "Abnormal Return to a Fundamental Analysis Strategy". The Accounting Review.

Amir, E. 1993. “The Market Valuation of Accounting Information: The Case of Postretirement Benefits Other Than Pensions". The Accounting Review 68.

Ball, R. and P. Brown. 1968. "An Emperical Evaluation of AAccounting Income Numbers". Journal of Accounting Research 6.

Beaver, W. H. 1968. "The Information Content of Earnings". Journal of Accounting Research 6.

Beaver, W.H. and McNichol. 1998. "The Characteristic and Valuation of Loss Reserves of PropertyCausalty Insurance Industry". Review of Accounting Studies.

Bhattacharya. 1979. "Imperfect Information, Dividend Policy, and the Bird in the Hand Fallacy". Bell Journal of Economic 10.

Brigham, E. F., L. C. Gapenski and P. R. Daves. 1998. “Intermediate Financial Management". Sixth Edition. The Dryden Press.

Dechow, P. M. 1994. "Accounting Earnings and Cash Flows as Measures of Firm Performance: The Role of Accounting Accruals". Journal of Accounting and Economics 18.

Financial Accounting Standards Board. 1978. Financial Statement: "Statement of Cash Flows". SFAS 95 Nopember.

Francis, J. and K. Schipper. 1999. "Have Financial Statements Lost their Relevannce ?" Journal of Accounting Research.

Gujarati, Damodar, 2003, “Ekonometrika Dasar" (terjemahan), Penerbit Erlangga, Jakarta.

Harianto, F. dan S. Sudono. 1998. "Perangkat dan Teknik Analisis Investasi di Pasar Modal Indonesia". PT. Bursa Efek Indonesia.

Institute for Economic and Financial Research. 2000. Jakarta: Indonesian Capital Market Directory. Institute for Economic and Financial Research. 2001. Jakarta: Indonesian Capital Market Directory. Institute for Economic and Financial Research. 2002. Jakarta: Indonesian Capital Market Directory. Institute for Economic and Financial Research. 2003. Jakarta: Indonesian Capital Market Directory. Institute for Economic and Financial Research. 2004. Jakarta: Indonesian Capital Market Directory. Institute for Economic and Financial Research. 2005. Jakarta: Indonesian Capital Market Directory. Institute for Economic and Financial Research. 2006. Jakarta: Indonesian Capital Market Directory.

Kormedi, R. and R. Lipe. 1987. "Earning Innovations, Earnings Persistence, and Stock Return". Journal of Business 60.

Landsman, W. 1986. "An Emperical Investigation of Pensions Fund Property Rights". The Accounting Review 61.

Machfoedz, M. 1994. "Financial Ratio Analisis and the Prediction of Earnings Changes in Indonesia“. Yogyakarta: Gadjah Mada University Business Review.

Manurung, Jonni., Santi B. Siahaan., 2004, "Prediksi Harga dan Imbal Hasil Investasi Saham Dari The Rice-Earnings Ratio Model Pada Bursa Efek Indonesia". Jurnal Manajemen dan Bisnis 3. Universitas Katolik Santo Thomas SU. 
Manurung, Jonni. dkk. 2003. "Pasar Keuangan \& Lembaga Keuangan Bank \& Bukan Bank". Jakarta: Penerbit PT. Adler Manurung Press.

Manurung, Jonni, Adler H. Manurung dan Ferdinand D. Saragih. 2005. "Ekonometrika, Teori dan Aplikasi". Jakarta: PT. Elex Media Komputindo (Gorup Gramedia).

Miller and Rock. 1985. "Dividend Policy Under Asymetric Information". Journal of Finance 40.

Ohlson, J. 1995. "Earning, Book Value, and Dividend in Equity Valuation". Contemporary Accounting Research 11.

Ou, J. and S. Penman. 1989. "Financial Statement Analysis and the Prediction of Stock Return". Journal of Accounting and Economics 11.

Parawiyati dan Z. Baridwan. 1998. "Kemampuan Laba dan Arus Kas Dalam Memprediksi Laba dan Arus Kas Perusahaan Go Public di Indonesia". Jurnal Riset Akuntansi Indonesia 1.

Sandiyani, Y. dan Aryati. 2001. "Rasio Keuangan sebagai Prediktor Laba dan Arus Kas di Masa Yang Akan Datang". Media Riset Akuntansi, Auditing, dan Informasi 2.

Sartono, R. A. 1997. "Manajemen Keuangan." Edisi Ketiga. Yogyakarta: BPFE UGM.

Schipper, Khaterine and L. Vincent. 2003. "Earning Quality". Accounting Horizons 17.

Sloan, R. 1996. "Do Stock Prices Fully Reflect Information in Accruals and Cash Flow About Future Earning ?" The Accounting Review 71.

Taggart, Robert. 1977. "A Model of Corporate Financing Decisions". Journal of Finance.

Watt and Zimmerman. 1972. "Some Time Series Properties of Accounting Income". Journal of Finance.

Weston, J. F. and E. C. Thomas. 1992. "Managerial Finance" New York: CBS Collage Publishing. Wijayanti, Indriati. dkk. 2005. "Kemampuan Informasi Keuangan Memprediksi Perubahan Laba". Jurnal Bisnis dan Manajemen 5. Universitas Sebelas Maret Surakarta. 